\title{
Sciendo
}

\section{The Polish Experience in the Development of Smart Cities}

\author{
Magdalena Kisała \\ Department of Local Government Law \\ and Administrative Science \\ The John Paul II Catholic University of Lublin \\ Spokojna 1 \\ Lublin 20074, Poland, \\ Email: kisala@kul.lublin.pl
}

\begin{abstract}
In recent years, Poland has seen an increased migration of people to cities, which translates into significant urban population growth. This, in turn, raises new challenges in the performance of cities' tasks and responsibilities. Additionally, climate changes and the depletion of natural resources necessitate the modification of existing urban practices. Polish cities seek solutions which would enable social, economic and environmental demands to be reconciled so that urban spaces become friendly for the city's inhabitants and investors. Some Polish cities have applied the smart city concept to solve their problems. Despite the fact that the concept has been the subject of scientific research for many years, no universal definition of the smart city has been agreed upon. Analyzed assumptions of the smart city concept as well as the Polish experiences in the implementation indicate that the concept is dynamic and changes over time. It should be considered as a perpetual process unrestricted by a specific timeframe. This impedes the formulation of uniform, generally accepted assumptions of the concept since its existence is inscribed in the change related to urban development. This article claims that this would be a beneficial approach for formulating the general characteristics of the smart city that could be applicable to any city, and that could be employed regardless of the present challenges cities may face.
\end{abstract}

Keywords: case study, Poland, smart city, smart city features, urban development 


\section{Introduction}

According to the National Urban Policy 2023 (Krajowa Polityka Miejska), city dwellers make up approximately $60 \%$ of the Polish population. Cities constitute clusters of networks of companies, employees, knowledge and skills. They develop science, public services, business, and the economy. With a well-executed urban modernization, both smaller and larger urban centers can and should be transformed into engines of development on a local or broader, regional, national and European scale. On the other hand, the transformation of cities and a rapid growth of their population raise several social, economic and spatial problems. Therefore, cities seek new solutions for a successful management of such problems (National Urban Policy 2023, 2015, p. 3).

The smart city concept pertains to the operation of cities and assumes their development in various fields so that they become a friendly and attractive place to live in. It has been the subject of long-term scientific research. However, despite the studies, no generally accepted assumptions of the concept have been developed and no universal definition of the smart city has been agreed upon. The objective of the article is to expand the body of knowledge concerning circumstances which should emerge for a city to be considered a smart city, and the conditions which the city should meet so that the term 'smart city' becomes applicable to it. The smart city concept and its characteristics were explored using literature of the subject, the analysis of legal grounds for the development of smart cities in Poland, and smart city development experiences of Polish cities. The last section presents the conclusions and contributions of the work.

\section{Smart city concept}

According to Giffinger (2007), the concept 'smart city' is based on the following: smart economy, smart people, smart governance, smart mobility, smart environment and smart living. He describes each factor but does not define the term 'smart' (Giffinger, 2007). Other definitions examine the role of cutting-edge technologies in the development of the smart city (Carvalho, 2015; Santangelo, 2016) or consider smart city as a city which places people and communities in its core (Lara et al., 2016). Some others place a strong emphasis on the aspect of city management and the contribution of residents 
to urban development (Dameri, 2013; Letaifa, 2015; Caragliu, Del Bo \& Nijkamp, 2011). Moreover, the very term 'smart' is fuzzy and frequently replaced with alternative adjectives such as 'intelligent' or 'digital' (Albino, Berardi \& Dangelico, 2015). Such state of affairs justifies further research pertaining to the smart city concept and the formulation of further findings based on the existing knowledge.

Over the years, theoretical assumptions have evolved based upon empirical experiences of cities related to the implementation of the smart city concept as well as the changing awareness of city authorities and residents and their needs. The following three generations of smart cities can be identified based on such experiences: Smart Cities 1.0, Smart Cities 2.0, and Smart Cities 3.0 (Cohen, 2015).

Smart Cities 1.0 are characterized by the implementation of modern technologies, frequently under the influence of technology suppliers, without proper preparation, suitable understanding of the consequences the applied solutions may bear and the way they may affect the quality of citizens' lives. City authorities play a leading role in Smart Cities 2.0. They initiate the change, focus on technological solutions as tools enabling the improvement of the quality of residents' lives. Smart Cities 3.0 constitutes a new generation of cities. They stress equality, social integration and participation of residents in transformation projects. The residents co-create cities. The projects do not focus upon technologies but upon problem-solving (Cohen, 2015).

Such a classification marks how the approach to urban development has changed and points the direction in which the smart city concept evolves. The evolution impedes the formulation of uniform, generally accepted assumptions of the concept since its existence is inscribed in the change related to urban development. Moreover, depending upon the context in which the word functions, the understanding of the very term 'smart' may vary. It is also difficult to clearly define the catalogue of areas and scope of smart city operation. This is visible in the EU and national legal grounds on urban development, which are updated and amended, with new urban development priorities being introduced. Therefore, given the foregoing findings, under the conditions of permanent flux, it seems more rational to provide universal characteristics of the smart city which may be applied to any city and which may be employed regardless of the present challenges cities face. The characteristics are as follows:

a) Effectiveness: the city identifies and satisfies the needs of its inhabitants; 
b) Flexibility: the city is prepared to act swiftly when the situation requires it and to adapt to changing conditions;

c) Efficiency: the city exploits available resources in a sustainable way;

d) Innovativeness: the city is able to consciously pursue novel solutions and technologies in order to use them optimally for solving the city's problems and increasing the quality of residents' lives;

e) Participation: the city co-creates the urban fabric with its inhabitants, the inhabitants become real co-decision makers;

f) Having a vision of the city's development set forth in strategic documents, which is acceptable to inhabitants, and undertaking joint actions to make this vision a reality.

Consequently, a smart city is able to define its capacity to act, of satisfying the needs of its inhabitants, of identifying urban problems and finding means to solve them taking into account the residents' opinions. It puts the urban development vision into practice. Such features characterize a smart city regardless of area, population, value of investments or the number of implemented technologies. A smart city has the ability to exploit knowledge and skills that contribute to its harmonious development. A smart city is also a city which has the ability to adapt to technical, economic, political and social changes in the environment in which it operates.

\section{Legal grounds for the development of smart cities in Poland}

When discussing the legal grounds for the development of smart cities in Poland, two groups of regulations should be indicated: EU regulations and domestic regulations. The EU regulations include the following: the Leipzig Charter on Sustainable European Cities, the New Leipzig Charter which provides a key policy framework document for sustainable urban development in Europe, and the Pact of Amsterdam establishing the Urban Agenda for the EU. The domestic regulations include: the Act on the principles of development policy of 6 December 2006 (Ustawa o zasadach..., 2019; 2020), government policy papers, and resolutions passed by city authorities.

The selection of the EU regulations was made according to their binding nature and the subject matter which directly pertain to the operation and development of cities. The first EU document on urban development was the Leipzig Charter adopted during an informal ministerial meeting on urban 
development and territorial cohesion that took place in Leipzig on 24-25 May 2007. It was signed by all Member States represented by ministers responsible for urban development. The ministers agreed upon joint principles and strategies for urban development policies and undertook to incorporate the assumptions of the Charter into national documents. More than a decade later, despite the existing validity of the Charter's assumptions, problems such as climate crisis, resource deficiency, migration processes, demographic changes, and rapidly changing economies persist and have a direct impact upon the situation of cities across Europe. They may also lead to pressing and complex challenges aggravating social inequality. Such changes contributed to the update of the 2007 Charter and adoption of the New Leipzig Charter, which occurred at an informal meeting of EU Member States' ministers for urban affairs on 30 November 2020. It opts for an approach adapted to local needs and hinging cities' transformation on the integration of social, environmental and economic aspects of sustainable development (Ministry of Development Funds and Regional Policy of Poland, 2020, pp. 7-13).

The EU Urban Agenda (Pact of Amsterdam), announced on 30 May 2016, constitutes another key document. The pact specifies twelve priorities for urban development: inclusion of migrants and refugees; air quality; urban poverty; housing; circular economy; jobs and skills in the local economy; climate adaptation (including green infrastructure solutions); energy transition; sustainable use of land and nature-based solutions; urban mobility; digital transition; innovative and responsible public procurement. The document assumes that the achievement of the Agenda's objective will be more effective if it is executed at the city level within the framework of partnership where cities cooperate on voluntary basis. The aim of the partnerships is to develop a multi-level and cross-sectoral approach to management based upon the involvement of practitioners working within the city authority structures, and upon the case studies. Such an approach will lead to the formulation of an action plan offering proposals pertaining to better regulation, funding and knowledge related to the partnership (Urban Agenda for the EU, 2016).

The 2007 Leipzig Charter and the Urban Agenda indicate the necessity of reinforcing both national and regional urban policies in order to enhance the potential of cities and facilitate the coherent implementation of sustainable urban development at a local level. Additionally, the aforementioned EU documents bind Poland to implement their postulates and adjust these to domestic conditions and needs. These are reflected in the domestic regulations. 
The Act on the principles of development policy of 6 December 2006 (Ustawa o zasadach prowadzenia polityki rozwoju) authorizes actions to be taken primarily by local governments. However, it also authorizes the government administration to exploit the potential and competitive advantages of Polish cities and their functional areas to ensure sustainable social, economic and spatial development. The development policy constitutes a set of interrelated activities undertaken and implemented to ensure a lasting and sustainable development of the country, socio-economic, regional and spatial cohesion, to boost the competitiveness of the economy and create new jobs on a national, regional and local scale. The development policy is executed based upon development strategies, programs and program documents, and public policies.

The government policy papers that delineate the direction of the main effort, define the primary challenges that cities face, and describe the vision of urban development at various levels of specificity: Strategy for Responsible Development for the period up to 2020 (with the perspective for the period up to 2030) (Strategia na rzecz Odpowiedzialnego Rozwoju do roku 2020 (z perspektywa do 2030 r.)), National Strategy for Regional Development 2030 (Krajowa Strategia Rozwoju Regionalnego 2030, see Ministry of Development Funds and Regional Policy of Poland, 2019), and National Urban Policy 2023 (Krajowa Polityka Miejska 2023, see Polish Economic Society, 2015). These emphasize the exploitation of endogenous potentials of territories and their specialization in order to achieve sustainable development of the country, enhancement of the capacity of cities and urbanized areas for sustainable development and job creation, improvement of the quality of inhabitants' lives and prevention of negative consequences of uncontrolled suburbanization. These documents emphasize the exploitation of endogenous potentials of territories and their specialization in order to achieve sustainable development of the country. They also highlight the enhancement of the capacity of cities and urbanized areas for sustainable development and job creation, and improvement of the quality of inhabitants' lives. They also underline the need to counteract the negative phenomena of uncontrolled suburbanization.

The domestic regulations determining the smart city development in Poland also encompass resolutions passed by city authorities. They adopt the names of policies and strategies. The Regional Urban Policy of the Lublin Province (Regionalna Polityka Miejska Województwa Lubelskiego) is an example. It identifies three main areas requiring the support of urban policy, which include the following: development of external functions of cities resulting 
from the role individual urban centers play in servicing the region; enhancement of the economic basis of the city which serves to improve its competitiveness; and improvement of the attractiveness of the city as an area of life for residents (Department of Regional Policy of the Lublin Province, 2017). To this day, it is the only document of this type adopted in Poland. Documents for the Ślaskie and Łódzkie provinces are under development. Another example is the development strategies of individual provinces. The strategies take into account cities located in the region, strategies of specific cities or strategies pertaining to a specific urban activity, e.g., tourism, which encompass the needs and potentials of cities (Masik, Sagan \& Scott, 2021). Finally, the strategies are delivered in the framework of cities' cooperation having a temporal nature and covering a specific aspect of operation, e.g., transport, waste management, water supply, and sewage disposal.

In light of the foregoing, it can be argued that the EU regulations were formulated in a general manner and set out a general framework for urban development. This enables their postulates to be adapted to the needs of Polish urban centers. Both the abovementioned act and strategies emphasize the necessity for urban development in various fields. They highlight sustainable development in the social, economic, and environmental aspects and call for the use and enhancement of cities' capacities, stimulation of economic development, job creation, and improvement of the quality of inhabitants' lives.

While Polish cities are obliged by law to take action, they have not been uniform all across Poland. The cities are independent to carry out development plans. This assumption takes into account differences between cities regarding their territory, population, solutions implemented thus far and policies pursued, as well as various urban problems, conditions and potential. It ought to be noted that the transformation of cities in Poland specifically into smart cities is not a legal obligation. There are no normative acts in force which lay down the conditions a city must meet in order to acquire the smart city status. It is not the number of undertaken initiatives, applied technologies or their type which should determine the smart city status. Smart city is a city which is characterized by effectiveness, flexibility, efficiency, innovativeness, participation, having the vision for urban development and putting the vision into practice. In practice, the actions of city authorities and inhabitants, their activity and effectiveness will determine whether a city becomes a smart city. 


\section{Smart city development experiences of Polish cities}

The EU and domestic regulations analyzed herein determine the scope of development of Polish cities. The greatest effort was placed on the implementation of cutting-edge technologies related to environment protection and sustainable development in various aspects of the cities' operation. The Smart Water System operates in over 30 cities across Poland (Business Insider, 2020). The system enables automatic reading of all water meters simultaneously. It also prevents water losses, generates savings and facilitates management (Bak, 2018). The system also features automatic alarms when a fault is detected, as well as continuous flow monitoring. It reduces water losses which contributes to the emergence of environmental benefits and cost reduction (Business Insider, 2020).

Cities also exploit the Smart Energy system and develop low-carbon economy plans. Photovoltaic installations interface with the energy flow management system. A Smart Energy Controller monitors the installation and connected devices and circuits on a round-the-clock basis whereby controlling dozens of energy parameters in real time. In the event of any irregularities, the system automatically sends notifications and alarms (Business Insider, 2020). Intelligent lighting systems are being implemented in the country. The flagship smart city project in Szczecin is a smart LED lighting system. Per annum, it offers over 1.5 million Polish zloty savings and reduces carbon dioxide emissions by 2.7 thousand tons (Lewandowski, 2019).

Modern solutions for waste management are also developed. For example, a Municipal Waste Treatment Plant was built in Białystok (PUHP " $L E C H$ ", 2017). Not only does the plant process waste, it also introduces environmentfriendly solutions related to water recovery. All precipitation water from the plant (roofs, roads, ground) is recovered and used. Water from the municipal network is used at a minimum level for social needs. Heat recovery systems are in palace. The plant produces electricity and heat for its own needs as well as those of the city. Radioactive waste detection systems are operational. A radioactivity detector is operational at the entry gate to the plant, hence there is no danger of such waste entering the site. Novel solutions were implemented as a protective measure against unpleasant odors. Such odors never leave the unloading dock, thus the plant is not burdensome to the surrounding environment (PUHP "LECH”, 2017). 
Parks, squares and flower meadows are established in cities as an element of green areas development strategy. Wrocław adopted the Green Charter (Karta Zieleni) for the city's residential estates. It aims to develop a strategy for adapting green areas individually for each estate. The charter includes information emerging from strategic documents as well as specific guidelines on green areas development in specified locations on the estate. The project assumes the participation of residents and estate councils at every stage of drafting the strategy (Załęczny, 2019). For improved communication with residents, Kraków uses the Municipal System of Spatial Information (Miejski System Informacji Przestrzennej, see MSIP Krakow, 2019), which supplies the most important information about the city. Residents may use the system to submit their observations concerning greenery (MSIP Krakow, 2019).

Cities undertake measures in order to improve air quality. Within Kraków city limits, a ban on the use of solid fuels has been in force since 1 September 2019. The resolution on the introduction of restrictions in the use of installations utilizing fuel combustion in the Ślaskie Province was also adopted by the province assembly. A similar resolution was adopted by the assembly of the Mazowieckie Province, and the assembly of the Pomorskie Province, among others. Some of the resolutions adopted in several provinces introduce the obligation to replace old heating installations with modern ones, bans on using coal and/or wood for heating purposes, etc. The Warsaw Air Index was launched in Warsaw (Kubicka, 2021).

Gdańsk, which has received the prestigious ISO Smart City certificate as a city friendly to residents and the environment, seeks to use modern technologies to refine the quality of residents' lives by improving the dialogue with residents, supporting electromobility more effectively, enhancing public services and caring for clean energy production (Lewandowski, 2019; Masik \& Stepień, 2021).

Another area where the most significant changes are made concerns modern and sustainable transport systems (Cieśla, 2021). Cities such as Lublin, Świdnik, Warsaw, Wrocław, Kraków, Katowice, Poznań, Szczecin, Torun, Rzeszów, and Stalowa Wola introduced the City Bike service (Rower Miejski) as an alternative to traveling by car within the city. The approach of cities to road safety is changing (Zawieska \& Pieriegud, 2018). Cities restrict traffic in the city center area. The next step in terms of urban mobility that cities are considering is the introduction of autonomous buses. Cities also invest in transport, purchase eco-friendly buses, and develop and 
renovate road infrastructure. Kraków introduced the following Intelligent Transport Systems (ITS) (Inteligentne Systemy Transportowe): Traffic Tram Supervision System (TTSS) (System Nadzoru Ruchu Tramwajowego) and the Urban Traffic Control System (UTCS) (Obszarowy System Sterowania Ruchem). These enhanced the management of tram routes in the event of, e.g., possible breakdowns, and facilitated pedestrian and vehicle traffic, which increased traffic capacity by up to $25 \%$. Rzeszów developed smart stops infrastructure. The stops feature ticket machines and electronic passenger information systems. Intelligent video monitoring was also implemented. Wrocław developed the Wrocław Electric Vehicle Charging System (Wrocławski System Eadowania Pojazdów Elektrycznych) and implemented the Intelligent Parking (Inteligentne Parkowanie) pilot program (Lewandowski, 2019).

Cities also exploit information and communication technologies in city services. Cities such as Warsaw, Kraków, Radom, Lublin, Gdańsk, Wrocław, Łódź, and Poznań implemented the City Card system (Karta Miejska).

Cities put emphasis on computerization, develop the system of official e-services and focus on swift and efficient dissemination of information on all municipal matters among their residents. An example of such an approach is the city of Kielce. The city launched the Smart City Platform (Platforma Smart City) which provides access to data, processes, analyzes and visualizes it, as well as shares the data to offer public e-services (Lewandowski, 2019).

The civic budget constitutes an example of residents' participation in the city management process. A percentage of the city budget is allocated to investment initiatives and projects submitted directly by the local community (by individuals or organizations). The city is obliged to execute projects which are selected annually, based on the highest number of votes. (Korolewska \& Marchewka-Bartkowiak, 2015).

Additionally, Polish cities take part in partnerships in the framework of the Urban Agenda for the EU (2016). The country is a member of nine out of twelve partnerships established under AMUE. In two of these, Poland has the role of co-coordinator. In five of these, it participates at the city level, and in other four, at the ministerial level (Załęska, 2018, p. 13). The Partnership Initiative of Cities (Partnerska Inicjatywa Miast, see Ministry of Development Funds and Regional Policy of Poland, n.d.) is the Polish equivalent of these partnerships. It is a program aimed at the exchange and promotion of knowledge among cities and other stakeholders. It seeks to develop and 
deliver urban policies concerning the delivery of integrated urban policy by cities. Between 2017 and 2019, as a part of the initiative, the following three thematic networks were in operation: Urban mobility, Revitalization, and Air quality. In total, four joint meetings of all participating cities were held. Additionally, 16 network meetings were organized in over 20 Polish cities (Ministry of Development Funds and Regional Policy of Poland, n.d.). Two Polish cities, Warsaw and Wrocław, were recognized in the prestigious IESE Cities in Motion Index 2020 ranking (IESE, 2020). Out of 172 cities included in the ranking, Warsaw ranked the 54th, Wrocław the 88th. Additionally, in the IMD Smart City Index 2019 (IMD, 2019), which covers 102 cities across the globe, Warsaw ranked the 61st and Kraków the 69th.

The "HUMAN SMART CITIES. Smart cities co-created by inhabitants" (HUMAN SMART CITIES. Inteligentne miasta wspóttworzone przez mieszkańców) competition has been held since 2018. The competition addresses local governments and its aim is to draft pilot, implementationready, smart technological solutions and social innovations in the cities. Such solutions are aimed to improve the management and operation of the urban fabric, and consequently, make the city a friendlier place to live in. The Urban Lab project is another tool for promoting the smart city concept among local governments. The instrument stimulates the cooperation of cities with enterprises, R\&D institutions and NGOs. It aims to improve the quality of residents' lives via innovative solutions to identify problems, and to generate added value by means of municipal resources. The "Local Development" program (Rozwój lokalny) is also being delivered. The program is financed by the EEA and Norwegian Financial Mechanisms 2014-2021 with the total budget of 117.6 million euros. The program supports the comprehensive environmental, social, economic and institutional development of cities, including their smart management. In 2019, during the meeting of the V4 ministers in Bratislava, a cooperation agreement for the development of smart solutions was signed (Serwis Samorzadowy PAP, 2019).

In spite of the many positive changes indicated above, some areas listed in EU and national documents requiring reforms and improvements could also be identified. Poland is still one of the infamous leaders of the European Union in terms of air pollution (GreenMatch,2018). It is also among countries faced with water shortage (Climate Home News, 2019).

The spatial development where economic priorities prevail against the quality of life should also be reformed. Urban space is treated as a source of short-term income and construction-related chaos is prevalent. No long- 
term provisions exist in terms of wellbeing that would include access to green areas and pro-social and recreational infrastructure. The use of the city's spatial structure could be more consciously made.

Social housing is another area in need of attention. The housing resources are deficient, poorly managed and in poor condition. Thorough renovations are carried out very rarely. Uninhabited flats are also a problem. This may stem inter alia, from inadequate rental policy (IRMiR, 2018). The housing market and housing policy programs target both the most vulnerable population (low-income segments) and the average earning population. Increasing the availability of housing for the latter group is needed because of the emergence of a disturbing trend called the rent gap, which happens when people's earnings are too high to qualify for the subsidized council housing, but too low to rent an apartment at market price. (Ryś et al., 2020)

\section{Conclusions}

This article clarified the meaning of the smart city concept to show what it implies for the development of Polish cities. The smart city concept and its characteristics were explored using the literature on the subject, the analysis of legal grounds for the development of smart cities in Poland and experiences with smart city development of Polish cities. This article demonstrated that despite long-term scientific research, no generally accepted assumptions of the concept have been developed and no universal definition of smart city has been agreed upon. The present work provided universal characteristics of the smart city which may be applied to any city and which may be employed regardless of the present challenges that cities face. Smart city is a city which is characterized by effectiveness, flexibility, efficiency, innovativeness, participation, having the vision for urban development, and putting the vision into practice.

The article showed the legal basis for urban development but also illustrated that the transformation of cities in Poland specifically into smart cities is not a legal obligation. There are no normative acts in force which lay down the conditions a city must meet in order to acquire the smart city status. In practice, the actions of city authorities and inhabitants, their activity and effectiveness will determine whether a city becomes a smart city. 
The interest in smart city solutions in Poland is clearly growing, as shown by the examples presented in the article. However, due to the diversification of cities as regards location, potential and population, the scope of actions differs. The article argued that the smart city concept is dynamic and evolving and it becomes a departing point for further research. Cities which implement the concept should adapt it to their individual needs. They should undertake measures taking into account the evidence and needs of their inhabitants.

In conclusion, urban development which follows the assumptions of the smart city concept is a necessity. This is due to the objective need associated with issues of environmental protection and the growing awareness of inhabitants who make a choice of a specific city as a place to live in. Authorities cannot be indifferent to the needs and requirements of inhabitants.

Magdalena Kisała is an associate professor at the Department of Local Government Law and Administrative Science, Faculty of Law, Canon Law and Administration, The John Paul Second Catholic University of Lublin. Her research focuses on the functioning of local government and cooperation between the public and private sectors.

\section{References}

Albino, V.; Berardi, U. \& Dangelico, R. M. (2015), 'Smart cities: Definitions, dimensions, performance, and initiatives,' Journal of Urban Technology, vol. 22, no. 1, pp. 3-21. https://doi.org/10.1080/10630732.2014.942092

Bak, J. (2018), 'Wise use of water in smart cities-possibilities and limitations,' E3S Web of Conferences, vol. 30, art. 01014. https://doi.org/10.1051/ e3sconf/20183001014

Business Insider (2020), 'Smart cities to nie fantastyka. W Polsce już wyrastaja inteligentne miasta' [Smart cities are not a fantasy. Smart cities are already emerging in Poland], 21 December. Retrieved from https://businessinsider.com. pl/firmy/w-polsce-juz-wyrastaja-inteligentne-miasta/tdzv02m [accessed $15 \mathrm{Jan}$ 2021]

Caragliu, A.; Del Bo, C. \& Nijkamp, P. (2011), 'Smart cities in Europe,' Journal of Urban Technology, vol. 18, no. 2, pp. 65-82. https://doi.org/10.1080/1063073 2.2011 .601117 
Carvalho, L. (2015), 'Smart cities from scratch? A socio-technical perspective,' Cambridge Journal of Regions, Economy and Society, vol. 8, no. 1, pp. 43-60. https://doi.org/10.1093/cjres/rsu010

Cieśla, M. (2021), 'Modern urban transport infrastructure solutions to improve the safety of children as pedestrians and cyclists,' Infrastructures, vol. 6, no. 7, art. 102. https://doi.org/10.3390/infrastructures6070102

Climate Home News (2019), 'Poland faces threat of water crisis as rivers dry up,' 29 July. Retrieved from https://www.climatechangenews.com/2019/07/29/polandfaces-threat-water-crisis-rivers-dry/ [accessed $12 \mathrm{Jul} 2021$ ]

Cohen, B. (2015), 'The 3 generations of smart cities. Inside the development of the technology driven city,' Fast Company, 8 October. Retrieved from https://www. fastcompany.com/3047795/the-3-generations-of-smart-cities [accessed 16 Jun 2021]

Constitution of the Republic of Poland of April 2, 1997, Journal of Laws 1997, no. 78 , Item 483.

Dameri, R. P. (2013), 'Searching for Smart City definition: a comprehensive proposal,' International Journal of Computers \& Technology, vol. 11, no. 5, pp. 2544-2551. https://doi.org/10.24297/ijct.v11i5.1142

Department of Regional Policy of the Lublin Province (2017), Regionalna Polityka Miejska Województwa Lubelskiego [Regional Urban Policy of the Lublin Province]. Retrieved from https://umwl.bip.lubelskie.pl/upload/pliki//0RPMWL. pdf [accessed 3 Feb 2021]

Giffinger, R. (2007), Smart cities. Ranking of European medium-sized cities, Centre of Regional Science Report. Retrieved from http://www.smart-cities.eu/ download/smart_cities_final_report.pdf [accessed 14 Jan 2021]

GreenMatch (2018), 'Mapped: Europe's most and least polluted countries.' Retrieved from https://www.greenmatch.co.uk/blog/2018/11/mapped-europes-most-andleast-polluted-countries [accessed 12 Jul 2021]

IESE (2020), IESE Cities in Motion Index. Retrieved from https://media.iese.edu/ research/pdfs/ST-0542-E.pdf [accessed 19 Feb 2021]

IMD (2019), IMD Smart City Index 2019. Retrieved from https:/www.imd.org/ research-knowledge/reports/imd-smart-city-index-2019/ [accessed 4 Feb 2021]

IRMiR (2018), Mieszkalnictwo społeczne. Raport o stanie polskich miast [Social housing. Report on the state of Polish Cities], Observatory of Urban Policy, Institute of Urban and Regional Development, 15 March. Retrieved from http:// obserwatorium.miasta.pl/mieszkalnictwo-spoleczne-raport-o-stanie-polskichmiast/ [accessed 25 Jul 2021]

Korolewska, M. \& Marchewka-Bartkowiak, K. (2015), 'Budżet obywatelski jako przejaw aktywności społecznej—analiza doświadczeń na przykładzie jednostek samorządu terytorialnego' [Civic budget as a manifestation of social activity- 
an analysis of experiences on the example of local government units], Studia $B A S$, no. 4(44), pp. 123-140.

Kubicka, J. (2021), 'Uchwały antysmogowe w Polsce-aktualizacja' [Anti-smog resolution in Poland-an update]. Mapping Air, 9 March. Retrieved from https://mappingair.meteo.uni.wroc.pl/2021/03/uchwaly-antysmogowe-w-polsce/ [accessed $25 \mathrm{Jul} 2021$ ]

Lara, A. P.; Moreira Da Costa, E.; Zilinscki Furlani, T. \& Yigitcanlar, T. (2016), 'Smartness that matters: towards a comprehensive and human-centred characterisation of smart cities,' Journal of Open Innovation: Technology, Market, and Complexity, vol. 2, art. 8. https://doi.org/10.1186/s40852-016-0034-z

Letaifa, S. B. (2015), 'How to strategize smart cities: Revealing the SMART model,' Journal of Business Research, vol. 68, no. 7, pp. 1414-1419. https://doi. org/10.1016/j.jbusres.2015.01.024

Lewandowski, A. (2019), Przyktady Smart Cities. Jakie sq inteligentne miasta w Polsce? [Examples of Smart Cities. What are smart cities in Poland?], Almine, 4 August. Retrieved from https://almine.pl/smart_city_przyklady_polska/ [accessed 6 Feb 2021]

Masik, G.; Sagan, I. \& Scott, J. W. (2021), 'Smart City strategies and new urban development policies in the Polish context,' Cities, vol. 108, art. 102790, pp. 1-9. https://doi.org/10.1016/j.cities.2020.102970

Masik, G. \& Stępień, J. (2021), 'Smart Local Governance: The case of the GdańskGdynia-Sopot Metropolitan Area in Poland,' Journal of Urban Technology. https://doi.org/10.1080/10630732.2021.1930841

Ministry of Development Funds and Regional Policy of Poland (n.d.), Partnerska Inicjatywa Miast [Partner City Initiative]. Retrieved from https://www.gov.pl/ web/fundusze-regiony/partnerska-inicjatywa-miast [accessed 3 Feb 2021]

Ministry of Development Funds and Regional Policy of Poland (2016), Polityka miejska [Urban policy]. Retrieved from https:/www.gov.pl/web/funduszeregiony/polityka-miejska [accessed 3 Feb 2021]

Ministry of Development Funds and Regional Policy of Poland (2019), Krajowa Strategia Rozwoju Regionalnego 2030, Rozwój społecznie wrażliwy i terytorialnie zrównoważony [National Strategy of Regional Development 2030, Socially sensitive and territorially balanced development]. Retrieved from https://www. gov.pl/web/ia/krajowa-strategia-rozwoju-regionalnego-2030-ksrr [accessed 15 Jan 2021]

Ministry of Development Funds and Regional Policy of Poland (2020), Nowa Karta Lipska. Transformacyjna siła miast na rzecz wspólnego dobra [The New Leipzig Charter. The transformative power of cities for the common good]. Retrieved from https:/www.gov.pl/attachment/a56e8572-34f8-4d40-b7bc-2d23d16f0dee [accessed 6 Feb 2021] 
MSIP Krakow (2019), 'MSIP - ogólnie czym jest MSIP?' [Municipal Spatial Information System-What is MSIP in general terms?] Retrieved from https://msip.krakow.pl/223757,artykul,msip__ogolnie_czym_jest_msip_.html [accessed 17 Dec 2020]

Polish Economic Society (2015), Krajowa Polityka Miejska 2023. Retrieved from http://www.pte.pl/pliki/2/21/KrajowaPolitykaMiejska.pdf [accessed $30 \mathrm{Jul}$ 2021]

PUHP "LECH” (2017), 'Zakład Unieszkodliwiania Odpadów Komunalnych w Białymstoku' [Municipal Waste Disposal Plant in Białystok], Przedsiębiorstwo Usługowo-Handlowo-Produkcyjne "LECH" Spółka z o.o. Retrieved from http:// www.lech.net.pl/pl/ofirmie/zuokbialystok/ [accessed 4 Feb 2021]

Ryś, R.; Górny, P.; Sobol, A. \& Muzioł-Węcławowicz A. (2020), Wyzwania i rekomendacje dla krajowej polityki miejskiej [Challenges and recommendations for the national urban policy], Report of thematic expert groups of the Congress of Urban Policy 2019. Shaping space. Transport and urban mobility. Environment and adaptation to climate change. Housing. Retrieved from http:// obserwatorium.miasta.pl/wp-content/uploads/2020/07/raport-wyzwania-irekomendacje-krajowa-polityka-miejska-Rajmund-Ry\%C5\%9B-Pawe\%C5\%82G\%C3\%B3rny-Agnieszka-Sobol-Alina-Muzio\%C5\%82-Wec\%C5\%82awowicz.pdf [accessed 6 Feb 2021]

Santangelo, M. (2016), 'Una ciudad (¿más?) inteligente’ [A (more?) intelligent city], Nóesis: Revista de Ciencias Sociales y Humanidades, vol. 25, no. 49, pp. 65-77. https://doi.org//10.20983/noesis.2016.12.5

Serwis Samorzadowy PAP (2019), 'Smart narzędzia. MIiR o instrumentach wsparcia dla rozwoju idei smart city w Polsce' [Smart tools. MIiR on support instruments for the development of the smart city idea in Poland], 9 October. Retrieved from https://samorzad.pap.pl/kategoria/archiwum/smart-narzedzia-miir-oinstrumentach-wsparcia-dla-rozwoju-idei-smart-city-w [accessed 4 Feb 2021]

Urban Agenda for the EU (2016), Pact of Amsterdam. Retrieved from https://ec.europa. eu/regional_policy/sources/policy/themes/urban-development/agenda/pact-ofamsterdam.pdf [accessed 11 Nov 2020]

Ustawa o zasadach... (2019), Ustawa z dnia 6 grudnia 2006 r. o zasadach prowadzenia polityki rozwoju [Act of December 6, 2006 on the principles of development policy], Journal of Laws, 2019, Item 1295; 2020, Item 1378.

Załęczny, P. (2019), 'Program Zielone Karty dla Maślic' [The Green Charter Program for Maślice], Zielony Wrocław, 16 April. Retrieved from https://www.wroclaw. pl/srodowisko/zielone-karty-dla-maslic-pilotaz-programu [accessed 6 Feb 2021]

Załęska, M. (2018), 'Agenda Miejska UE. Polskie Doświadczenia' [The Urban Agenda of the EU: Experience of Poland], Bliżej Brukseli, no. 21, pp. 12-17. 
Retrieved from https://www.malopolska.pl/publikacje/blizej-brukseli/21-blizejbrukseli-agenda-miejska [accessed 14 Jan 2021]

Zawieska, J. \& Pieriegud, J. (2018), 'Smart city as a tool for sustainable mobility and transport decarbonisation,' Transport Policy, vol. 63, pp. 39-50. https://doi. org/10.1016/j.tranpol.2017.11.004 